\title{
The state and the profession: the politics of the double bed
}

\author{
Rudolf Klein
}

Centre for the Analysis of Social Policy,

School of Social Sciences, University of Bath,

Bath BA2 7AY

Rudolf Klein, MA, director

BrMed f 1990;301:700-2

Drawing by $E H$ Shepard (1948) (Reproduced by permission of the estate of E H Shepard)
In retrospect it is clear that those who fought Nye Bevan's plans for setting up the National Health Service were right in at least one important respect. The setting up in 1948 marked a revolution in the relation between the state and the medical profession. But it was not quite the revolution that the critics had anticipated and prophesied. It did not mean the triumph of bureaucracy over professionalism or the subordination of doctoring to ministerial diktat. Instead, it created a situation of mutual dependency. On the one hand the state became a monopoly employer: effectively members of the medical profession became dependent on it not only for their own incomes but also for the resources at their command. On the other hand the state became dependent on the medical profession to run the NHS and to cope with the problems of rationing scarce resources in patien care. The subsequent history of the NHS can, in institutional and political terms, be seen largely as a series of attempts to manage this mutual dependency, to find ways of accommodating the frustrations and resentments of both sides in the partnership, and to devise organisational strategies for containing conflicting interests within the framework of the NHS. My theme, in short, is that it is possible to understand what is happening in the NHS today-and indeed what has happened over the past 40 odd years-only if it is seen
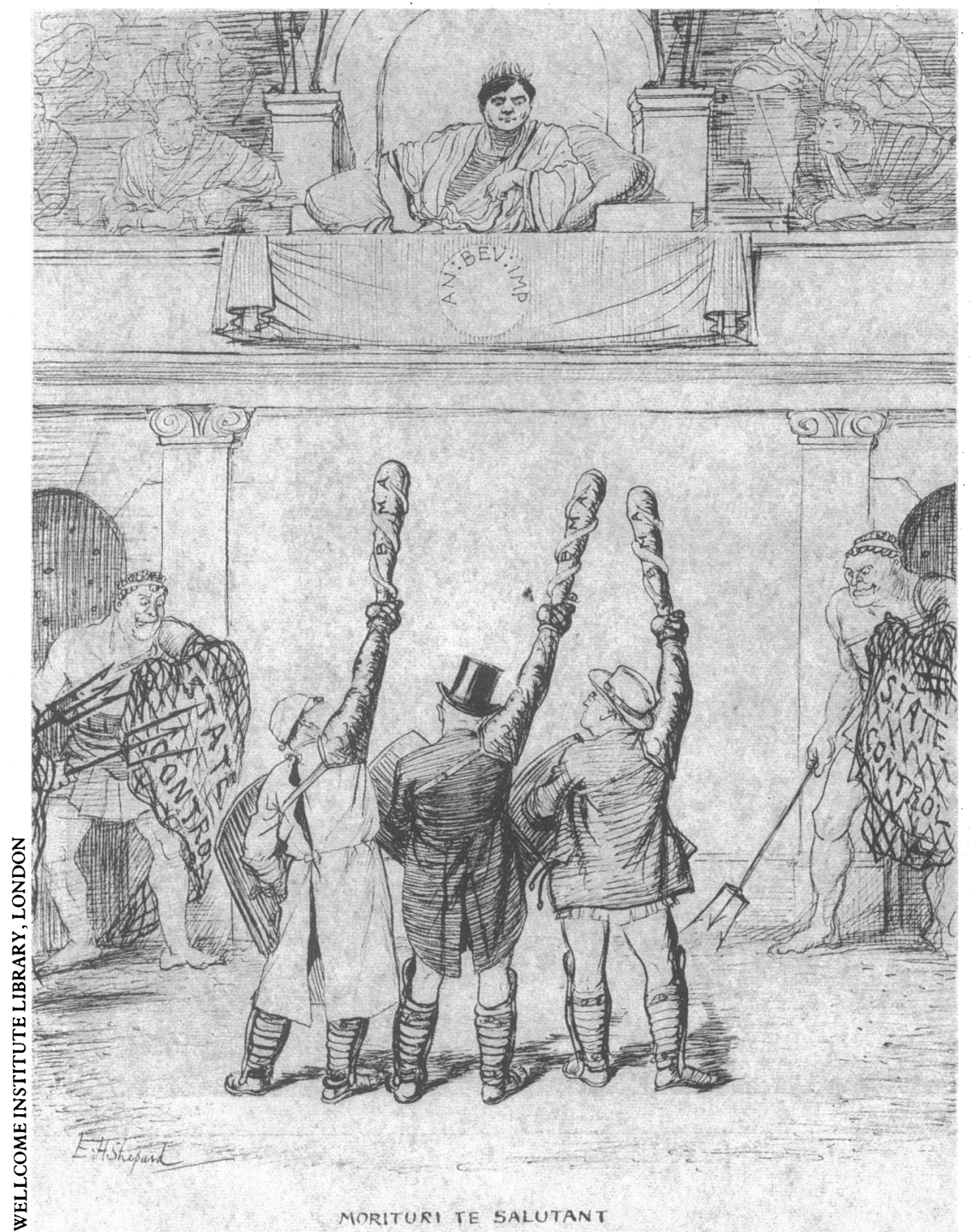

as the stage on which the tensions built into its design are acted out. For the drama to conflict between state and profession is not an accidental byproduct of Britain's health care, it is the inevitable outcome of the financial and institutional framework that was set up in 1948. The puzzle is not that there has been so much conflict but that it has, so far, been possible to cope with it in such a way as not to destroy the NHS.

\section{Symmetrical frustration}

For 40 years the state and profession have been engaged in a repetitive cycle of confrontation. The issues have changed over time (though some constant themes are evident), and so have the personalities, as Labour secretaries of state have yielded to Conservative ones in the demonology of the medical profession (the special place of $\mathrm{Mr}$ Kenneth Clarke in this respect mainly reflects a lack of collective memory). Yet despite 40 years of bickering and recrimination the NHS has survived. Despite decades of denouncing the inadequacies of the NHS the medical profession remains dedicated to its defence. Despite the political costs of being regularly pilloried in the media for its stinginess the government proclaimed its loyalty to the principles of the NHS in the 1989 review. Despite the frequent protestations that the NHS is on the point of collapse public support remains undiminished. Consensus about the desirability of the NHS has survived and contained the conflict within it. How has this been achieved? What are the prospects of maintaining the balance in the coming decades?

One answer may be that there is a neat symmetry of frustration in the relationship between the state and the profession. In the case of the state it is its control over money that makes the NHS such an attractive proposition; in the international context the NHS is quite clearly" the "best buy" model for delivering comprehensive universal health care at the lowest price and in a reasonably equitable way. ' But it is, of course, precisely this control that frustrates the medical profession-in Enoch Powell's words: "The unnerving discovery every Minister of Health makes at or near the outset of his term of office is that the only subject he is ever destined to discuss with the medical profession is money." If the medical profession is not engaged in wrangles over its own pay it is battling for more funds for the NHS. Conversely, the NHS provides a setting in which the medical profession can exercise its skills with almost complete autonomy: within the limits of the available resources NHS doctors have been more free to exercise their professional judgments than their peers in the United States and in most ather Western countries. But it is, of course, precisely this autonomy that frustrates the government. If ministers are to achieve their priorities they are sooner or later driven to question medical practices and to search for ways of achieving some sort of influence over clinical decisions on such matters as, for example, lengths of stay or expenditure on drugs.

There are other factors also. In the case of the state, to concede autonomy to the medical profession is also to delegate responsibility for rationing: the NHS allows political decisions about resources to be disguised as clinical decisions about individual patients. In the case of the medical profession the system allows it largely to control entry and thus to assure employment for its members: the fact that doctors (like every other group) frequently consider themselves to be underpaid should 
not disguise the fact that the NHS guarantees them an income linked to the going rate for the professional middle classes. In the past the medical profession has done well out of the intervention of the state in medical care: a profession that had a sizable proletariat of insecure and poorly paid practitioners before 1911 has become collectively more secure and wealthier with each step in the evolution of the state system. Above all the NHS commands loyalty that transcends self interest, whether political or professional. It is because there is a general perception that the NHS is an admirable instrument for distributing health care fairly - that it is preferable to have a system where the incentives are to do too little, even if this means more queues, rather than do too much - that consensus has hitherto contained conflict and that the individual discontents have not led to a repudiation of the 1948 settlement.

Once we recognise, however, that these discontents are not just accidental aberrations but are built into the design of the NHS it follows that we cannot simply take the comfortable view that the future will be like the past. Having lived with these tensions for the past 40 years why should the NHS not accommodate them in coming decades? Given the certainty that conflict will continue and the possibility that the NHS may be living off an inherited but not necessarily renewable capital of commitment and loyalty is it possible to devise better strategies for managing the resentment generated by the mutual dependency of the state and the profession? What, in particular, can be learnt from past efforts to do so?

\section{Economy before logic}

One option, clearly, is to try to transmute political into technical issues: to fly on automatic pilot instead of engaging in a constant dispute about the route. Here the most obvious example is the attempt, stretching back to the early days of the NHS's history, to devise a formula for determining medical pay by analysing data rather than by engaging in a power struggle. It was to achieve precisely this aim that the government set up the Royal Commission on Doctors' and Dentists' Remuneration in $1957^{3}$ - the independent review body that devised both the notion of and the mechanism for comparing medical incomes with other professional incomes; the mechanism still survives today. As Professor John Jewkes pointed out in a dissenting memorandum:

The responsible Government Departments are in the extraordinary, and perhaps unique, position that they largely control the demand for, the supply of, and the price offered for the services of the medical and dental professions. . . It is this grip of the Government which explains why the profession has spent so much time, inevitably without success, in search of a formula which would in perpetuity protect it against arbitrary action on the part of the State. For the same reason it is only to be expected that, in any new major settlement with the professions, doctors and dentists will not be wholly, nor perhaps even primarily, concerned with the new level of earnings established. They will also be vitally interested in the light thrown by these decisions, in terms of works not of words, upon the view which the Government holds as to the place of the medical profession in society....

Subsequently, however, both Labour and Conservative administrations, including the present one, have shown their belief that the logic of national economic management must override the logic of the NHS pay determination machinery. Most dramatically the first review body - originally appointed in 1962-resigned in 1970 because the government was prepared to implement only half the $30 \%$ increase recommended. It was this which precipitated a major confrontation between the government and the profession, with the BMA advising its members not to cooperate in NHS administration or to sign national insurance medical certificates in protest against what was seen as "arbitrary action" by the state. The successor body was appointed on the understanding that its recommendations would not be rejected or modified by the government "unless there were obviously compelling reasons for so doing." "In the event, Britain's stormy economic history has provided quite a few such compelling reasons. The experience of pay determination therefore warns against optimism about the scope for insulating the NHS from political or economic pressures by means of technical fixes, whether by devising formulas for pay or formulas for determining its budget by allocating a fixed proportion of the national income.

\section{Engineering consensus}

Inevitably, it would seem, the management of mutual dependency and the resulting conflict depends on the political system - that is, political context, style, and conventions that shape the relationship between the state and the profession. Here it is possible to identify some important changes that distinguish the past decade from the previous 30 years. From the 1950 s to the 1970s the NHS provided perhaps the most convincing text for those who argued that Britain had a corporatist policy making system, with policy emerging from a process of negotiation and bargaining between Whitehall ministries and interest groups like the medical profession, industry, and the trade unions. ${ }^{56}$ It was a system in which differences might on occasion erupt into open conflict-as was indeed the case with the NHS - but where all participants were constrained by the knowledge that they had a shared interest in maintaining the framework. In the words of Sir George Godber, one of the main architects of change at the time, ${ }^{7}$ it was a period in which progress was largely made within the NHS by a process of engineering consensus.

In the 1980s, however, the Conservative government has explicitly challenged and repudiated the notion of a corporatist approach to policy making. Corporatism has been identified as a source of stagnation, institutional sclerosis, and the pursuit of self interest at the expense of the public interest. Consensus became the enemy instead of being the objective. It is a view of politics that sees a strong state dealing with strong citizens (strong because they are empowered by the giving of more resources and more say over their lives, whether in housing or education) rather than with interest groups like professions, which act as the agents of their members. It therefore implies a quite different political style; the old conventions have been relegated to the history books. It also implies a different view of the "place of the medical professional in society": like other professions, such as law, it becomes increasingly regarded as just one more lobby or pressure group rather than carrying some special imprimatur deriving from the nature of its expertise or its claims to represent a particular set of values.

\section{Exclusion in 1989}

The contrast can be illustrated by comparing the 1974 reorganisation of the NHS with that now being implemented. In 1974 corporatism as interpreted by the secretary of state, Sir Keith (now Lord) Joseph, ruled supreme. The new design of the NHS was hammered out in consultation with the professions. The product of committees, it spawned yet more committees in an attempt to ensure that every interest in the NHS would be represented. ${ }^{8}$ In doing so it universalised veto-power and by seeking to satisfy 
everyone managed to please no one. Indeed, it seemed to show that corporatism led only to rigidity and inflexibility. Conversely, the 1989 review seemed to be based on the belief that it would be possible to avoid repeating the mistakes of the past by not trying to consult or satisfy any of the NHS interest groups. It was the first time in the history of the NHS that the medical profession was systematically excluded from the decision making process leading up to the review; an exclusion which may perhaps explain the subsequent bitterness rather more than actual policy content. Indeed, the BMA's subsequent advertising campaign served largely to advertise the fact of the profession's exclusion. It drew attention to the profession's loss of privilege: in happier, corporatist days the profession had its own direct and private links with civil servants and ministers - an iron triangle of consultation that turned out to be made of cardboard in the 1980s.

Looking to the future, therefore, it seems clear that the way in which the relationship between the state and the medical profession is managed will depend not on what happens within the NHS but on what happens to Britain's political system. If the 1980 s turn out to be an interregnum - if the assault on the role of interest groups proves to have exhausted itself-then there may well be a return to the politics of the double bed: peace between partners through propinquity.
The emphasis might then once again be on trying to engineer consensus through the participation of professions, trade unions, and other interest groups in the policy process-the European rather than the American model. It seems unlikely, however, that memories of the 1970s and earlier decades will disappear entirely or that the risks of corporatist stagnation will be quietly accepted. If the professions are once again to be seen as partners in the policy process rather than pressure groups exclusively pursuing their own interest it may mean that they will also have to show their willingness and capacity to adapt and change and, above all, to recognise that they are accountable as much to the society that grants them their privileged status as to their own members. If such a new political settlement cannot be achieved, however, it seems unlikely that the NHS will survive long into the twenty first century.

1 Organisation for Economic Cooperation and Development. Financing and delivering health care. Paris: OECD, 1987

2 Powell JE. Medicine and politics. London: Pitman Medical, 1966.

3 Royal Commission on Doctors' and Dentists' Remuneration. Report. London: HMSO, 1960. (Cmnd 939.) (Chairman: Sir Harry Pilkington.)

4 Review Body on Doctors' and Dentists' Remuneration. Report. London: HMSO, 1971. (Cmnd 4825.) (Chairman: Lord Halsbury.)

5 Eckstein H. Pressure group politics. London: Allen and Unwin, 1960.

6 Beer SH. Britain against itself. London: Faber and Faber, 1982.

7 Godber G. Change in medicine. London: Nuffield Provincial Hospitals Trust, 1975.

8 Klein R. The politics of the NHS. 2nd ed. London: Longman, 1989.

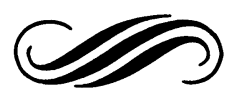

\section{Cover illustrations}

The cover of this issue illustrates some of the most important landmarks in medicine recorded in the $B M F$ in the past 150 years.

Eight plants that have been important in medicine are illustrated:

Ammi visnaga, the effect of which in relieving angina led to the synthesis of sodium cromoglycate and amiodarone; Catharanthus roseus (the Madagascar periwinkle), the source of vinblastine and vincristine; Digitalis lanata; Digitalis purpurea; Glycyrrhiza glabra-the effect of liquorice in relieving indigestion led to the production of carbenoxolone; Melilotus officinalis, the source of dicoumarol; Physostigma venenosum, the source of physostigmine; Podophyllum hexandrum.

The remaining illustrations are reminders of some important articles that have been published in the journal: Sickle cells'; leukaemia cells ${ }^{2-4}$; micrococci-grape shaped groups (magnified $\times 2000)^{56} ;$ micrococci in an abscess wall (magnified $\times 1600)^{56} ; x$ ray film of a hand 7 Spencer Wells forceps ${ }^{8}$; electrocardiogram ${ }^{9}$; Ornithodoros moubata, the vector of "tick fever" "11; the Anopheles mosquito $^{12-14}$; butterflies ${ }^{15}$; sea snake. ${ }^{16}$

1 Allison AC. Protection afforded by sickle cell trait against subtertian malarial infection. Br Med F 1954;i:290-4.
2 Court Brown WM, Doll R. Mortality from cancer and other causes after radiotherapy for ankylosing spondylitis. $\mathrm{Br} \mathrm{Med}$ f 1965; ii: $1327-32$.

3 Stewart A, Webb J, Hewitt D. A survey of childhood malignancies. Br Med f 1958;i:1495-508.

4 Gardner MJ, Snee MP, Hall AJ, Powell CA, Downes S, Terrell JD. Results of case-control study of leukaemia and lymphoma among young people near Sellafield nuclear plant in West Cumbria. Br Med F 1990;300:423-9.

5 Ogston A. Report upon micro-organisms in surgical diseases. BrMed F 1881;i:369-75.

6 Williams REO, Noble WC, Jevons MP. Isolation for the control of staphylococcal infection in surgical wards. BrMed f 1962;ii:275-82.

7 Anonymous. The new kind of radiation. $\mathrm{Br} M e d \mathcal{F}$ 1896;i:238. (Photograph by AJC Swinton.)

8 Wells TS. Remarks on forcipressure and the use of pressureforceps in surgery. $\mathrm{Br}$ Med F 1879;i:926-8;ii:3-4.

9 Lewis T. Electrocardiography and its importance in the clinical examination of heart affections. Br Med $\mathcal{F} 1912$;i: 1422-3.

10 Ross PH, Milne AD. "Tick fever." Br Med F 1904;ii: 1453-4.

11 Dutton JE, Todd JL. The nature of tick fever in the eastern port of the Congo Free State. Br Med F 1905;ii:1259-60.

12 Shortt HE, Garnham PCC, Malamos B. The pre-erythrocytic stage of mammalian malaria. Br Med F 1948;i:192-4.

13 Shortt HE, Garnham PCC, Covell G, Shute PG. The preerythrocytic stage of human malaria, Plasmodium vivax. BrMed F 1948; i: 547 .

14 Shortt HE, Fairley NH, Covell G, Shute PG, Garnham PCC. The pre-erythrocytic stage of Plasmodium falciparum. A preliminary note. $\mathrm{Br}$ Med F 1949;ii:1006-8.

15 Clark CA. Prevention of Rh haemolytic disease. $\mathrm{Br} \mathrm{Med} \mathcal{f}$ 1967;iv:7-12.

16 Reid HA. Sea snake bites'. Br Med F 1956;ii:73-8. 